\title{
PENGEMBANGAN MULTIMEDIA INTERAKTIF PADA MATA PELAJARAN DASAR DAN PENGUKURAN LISTRIK
}

\author{
Muliyana $^{1^{*}, \text { Habibullah}^{1} \text {, Dwiprima Elvanny Myori }}{ }^{1}$ \\ ${ }^{1}$ Jurusan Teknik Elektro, Fakultas Teknik, Universitas Negeri Padang \\ *e-mail: muliyana129@gmail.com
}

\begin{abstract}
Abstrak - Penelitian ini bertujuan untuk menghasilkan multimedia pembelajaran interaktif yang valid, praktis, dan efektif untuk digunakan dalam proses pembelajaran mata pelajaran Dasar dan Pengukuran Listrik (DPL) pada kompetensi dasar memahami rangkaian arus bolak-balik di SMKN 1 Padang. Jenis penelitian ini adalah penelitian dan pengembangan (Research and Development) dengan menggunakan model pengembangan 4D yang terdiri dari 4 tahap yaitu tahap pendefinisian (Define), tahap perancangan (Design), tahap pengembangan (Develop) dan tahap penyebaran (Disseminate). Berdasarkan hasil penelitian, pengujian validitas multimedia interaktif yang dilakukan oleh tiga orang validator diperoleh nilai rata-rata sebesar 0,835 dengan kategori valid. Hasil uji praktikalitas guru diperoleh sebesar $100 \%$ dan siswa sebesar $89,8 \%$ dengan kategori sangat praktis. Hasil uji efektivitas didapatkan ketuntasan klasikal sebesar 84,6\% dengan kategori efektif. Dengan demikian penelitian ini telah menghasilkan multimedia pembelajaran DPL yang valid, praktis dan efektif.
\end{abstract}

Kata Kunci : Multimedia Interaktif, Adobe Flash CS6, Dasar dan Pengukuran Listrik

\begin{abstract}
Abstrack - This research aims to produce interactive multimedia learning that is valid, practical, and effective for use in the process of learning basic subjects and electrical measurements (DPL) on basic competencies to understand the series of alternating current in SMKN 1 Padang. The type of research used in this research is Research and Development. The research development uses 4D development model which consists of 4 stages; Define, Design, Development and Dissemination. Based on the results of research, interactive multimedia validity testing conducted by three validators obtained an average value of 0.835 with a valid category. The result of the teacher practicality test is $100 \%$ and the students is $89.8 \%$ with very practical category. The effectiveness of the test results obtained classical mastery of $84.6 \%$ with effective category. Thus, this research has resulted in a valid, practical and effective DPL learning multimedia.
\end{abstract}

Keywords: Interactive Multimedia, Adobe Flash CS6, Basic and Electrical Measurements

\section{PENDAHULUAN}

Pendidikan merupakan usaha yang dilakukan secara terencana yang bertujuan untuk mengembangkan potensi serta kemampuan siswa atau anak agar dapat mengalami perubahan menjadi yang lebih baik sehingga berguna bagi nusa dan bangsa. Kegiatan pendidikan di sekolah dilakukan dengan proses pembelajaran. Pembelajaran adalah konsep yang terdiri dari dua kegiatan yaitu belajar dan mengajar, proses pembelajaran merupakan interaksi antara siswa dengan guru mengenai materi pembelajaran. Proses pendidikan di sekolah sering dijumpai masalahmasalah umum yang menghambat tercapainya tujuan pendidikan yang telah direncanakan, seperti kurangnya sarana dan prasarana pembelajaran, kurangnya sumber belajar bagi siswa, dan lain sebagainya.

Sumber belajar merupakan sumber yang berupa data, orang atau wujud tertentu yang dapat digunakan oleh peserta didik dalam belajar, baik secara terpisah maupun secara terkombinasi sehingga mempermudah peserta didik dalam mencapai hasil belajar yang baik. Sumber belajar yang menempati posisi yang cukup strategis dalam 
rangka mewujudkan waktu belajar secara optimal adalah media pembelajaran [2][3]. Media pembelajaran merupakan komponen komunikasi yang berfungsi untuk membawa informasi dari pembawa pesan (guru) menuju penerima pesan (siswa). Media pembelajaran adalah media yang membawa pesan-pesan atau informasi yang bertujuan intruksional atau mengandung maksudmaksud pengajaran [1].

SMK Negeri 1 Padang merupakan salah satu sekolah kejuruan yang bertujuan untuk menciptakan tenaga kerja yang terampil dibidangnya. Salah satu bidang keahlian yang ada di SMKN 1 Padang adalah Teknik Instalasi Tenaga Listrik (TITL). Bidang keahlian TITL ini memiliki banyak mata pelajaran, salah satunya adalah Dasar dan Pengukuran Listrik (DPL). Mata pelajaran DPL memiliki tingkat keabstrakan yang tinggi sehingga menyebabkan siswa sulit memahami materi pembelajaran jika disampaikan secara verbal, sehingga berpengaruh terhadap hasil belajar siswa. Seperti yang ditunjukkan oleh persentase ketuntasan Ujian Tengah Semester (UTS) yang masih dibawah nilai Kriteria Ketuntasan Minimum (KKM) pada tabel 1.

Tabel 1. Persentase Nilai Ujian Tengah Semester (UTS) Siswa Kelas X TITL pada Semester Ganjil Mata Pelajaran Dasar dan Pengukuran Listrik di SMKN 1 Padang.

\begin{tabular}{cccccc} 
& Jumlah & \multicolumn{2}{c}{ Nilai } & 280 & \multicolumn{2}{c}{ Nilai $<80$} \\
\cline { 3 - 6 } & Siswa & Jumlah & $(\%)$ & Jumlah & $(\%)$ \\
\hline X & 32 & 21 & 65,62 & 11 & 34,38 \\
TITL & & & & & \\
A & & & & & \\
$\quad$ X & 27 & 6 & 22,22 & 21 & 77,78 \\
$\begin{array}{c}\text { TITL } \\
\text { B }\end{array}$ & & & & &
\end{tabular}

Sumber : Buku Nilai Guru Mata Pelajaran Dasar dan Pengukuran Listrik TP. 2016/2017

Berdasarkan observasi yang telah dilakukan di sekolah, metode belajar yang digunakan masih berpusat kepada guru, sehingga menyebabkan siswa bergantung kepada guru, begitu juga dengan media yang digunakan belum dapat membuat siswa belajar secara mandiri. Media yang umum digunakan oleh guru disekolah adalah buku pelajaran dan papan tulis. Media buku pelajaran dan papan tulis merupakan media yang sangat umum digunakan dan memiliki fungsi yang sangat penting dalam penyampaian materi, tetapi media tersebut masih memiliki kekurangan, seperti tidak dapat memberikan penjelasan langsung hanya dengan membaca, dan bagi siswa yang kurang disiplin aktivitasnya akan kurang karena sulit memahami materi dalam buku pelajaran atau modul, bahkan tidak dapat memvisualisasikan langsung suatu gambar seperti gambar gelombang atau gambar rangkaian yang jelas dan membutuhkan waktu lama untuk membuat gambar di papan tulis, sehingga menyebabkan siswa merasa bosan karena harus menunggu guru selesai menulis di papan tulis.

Mata pelajaran DPL adalah mata pelajaran yang menggambarkan tentang kelistrikan seperti dasar-dasar listrik, pengkuran listrik arus, tegangan, daya, hambatan, dan sebagainya. Sesuai dengan Kompetensi Dasar (KD) memahami rangkaian listrik arus bolak balik dengan indikator menggambarkan karakteristik arus bolak balik, respon elemen pasif, rangkaian seri paralel, daya dan faktor daya. Arus dan tegangan merupakan sesuatu yang bersifat abstrak, siswa akan sulit untuk memahami jika berbicara mengenai arus karena siswa hanya bisa membayangkan, sehingga menyebabkan salah pemahaman antara guru dan siswa jika guru hanya menjelaskan dengan teori atau dengan metode ceramah.

Oleh karena itu multimedia pembelajaran interaktif dapat menjadi alternatif yang tepat untukmengatasi permasalahan tersebut. Karena multimedia pembelajaran interaktif akan memberikan visualisai langsung terhadap siswa sehingga dapat berinteraksi langsung dengan media tersebut, contohnya media akan memberikan respon benar atau salah kepada siswa saat siswa menjawab soal evaluasi yang dimuat dalam media. Selain itu siswa juga dapat belajar secara mandiri dengan multimedia pembelajaran interaktif sehingga siswa akan lebih cepat memahami materi pelajaran tersebut. Multimedia pembelajaran berfungsi untuk menyampaikan pesan (pengetahuan, keterampilan, dan sikap) serta dapat merangsang pilihan, perasaan, perhatian, dan kemajuan siswa sehingga secara sengaja proses belajar terjadi, bertujuan, dan terkendali. Multimedia interaktif adalah suatu multimedia yang dilengkapi dengan alat pengontrol yang dapat 
dioperasikan oleh pengguna sehingga pengguna dapat memilih apa yang dikehendaki untuk proses selanjutnya [2]. Contohnya adalah pembelajaran interaktif dan aplikasi game. Media pembelajaran interaktif tersebut dibuat menggunakan Adobe Flash Pro CS6.

Adobe Flash Pro CS6 merupakan sebuah perangkat lunak komputer yang banyak digunakan untuk membuat gambar vektor maupun animasi dari gambar tersebut. Selain itu adobe flash juga mampu menghasilkan permainan, animasi, banner, menu interaktif, dan interaktif form isian serta untuk membuat situs web yang interaktif, menarik dan dinamis. Adobe flash mampu melengkapi media interaktif dengan beberapa simulasi, suara, animasi interaktif, dan lain-lain, sehingga pengguna sambilmendengarkan penjelasan mereka dapat melihat gambar animasi, maupun membaca penjelasan dalam bentuk teks. Flash tidak hanya menggabungkan elemen multimedia dengan action script, flash juga mempunyai kemampuan dalam membuat interaktif scripting, hal ini yang nantinya sangat berguna dalam pembuatan simulasi dan soal-soal interaktif. Adobe Flash juga menghasilkan file dengan ukuran yang kecil, tetapi dengan kualitas yang baik.

Dari penjelasan diatas, software adobe flash pro cs6 dapat digunakan dalam pembuatan multimedia pembelajaran interaktif. Berdasarkan pemaparan sebelumnya, perlu dilakukan penelitian dan pengembangan multimedia pembelajaran interaktif pada mata pelajaran dasar dan pengukuran listrik pada kompetensi dasar memahami rangakaian listrik arus bolak-balik kelas $X$ TITL B di SMK Negeri 1 Padang.

\section{METODE}

\section{A. Desain Penelitian}

Jenis penelitian yang digunakan pada penelitian ini adalah penelitian dan pengembangan (Research and Development). Metode penelitian dan pengembangan (Research and Development) adalah metode penelitian yang digunakan untuk menghasilkan sebuah produk tertentu, dan menguji kefeektifan produk tersebut [7]. R \& D atau Research and Development adalah metode penelitian yang secara sengaja, sistematis, bertujuan atau diarahkan untuk mencari, menemukan, merumuskan, memperbaiki, mengembangkan, menghasilkan, dan menguji keefektifan suatu produk, metode/strategi/cara, jasa, atau prosedur tertentu agar menjadi lebih unggul, baru, efektif, efesien, produktif, dan bermakna [5].

\section{B. Subjek Penelitian}

Subjek dalam penelitian ini adalah multimedia interaktif pada mata pelajaran dasar dan pengukuran listrik. Siswa kelas X TITL B SMKN 1 Padang dan satu orang guru mata pelajaran dasar dan pengukuran listrik sebagai responden. Penentuan kelas dilakukan dengan teknik purposive sampling, yaitu memilih kelas dengan berdasarkan tujuan yaitu melakukan pengembangan multimedia pembelajaran intaraktif untuk kelas yang memiliki ketuntasan klasikal lebih rendah.

\section{Model Pengembangan}

Model pengembangan yang digunakan dalam penelitian ini adalah model pengembangan 4-D yaitu Define (Pendefinisian), Design (Perancangan), Develop (Pengembangan), dan Disseminate (Penyebaran).

\section{Instrumen Penelitian}

instrumen penelitian adalah alat yang digunakan dalam pengumpulan data atau informasi yang berhubungan dengan penelitian [4]. Instrumen yang digunakan dalam penelitian ini adalah untuk mengumpulkan data yang berhubungan dengan validitas, praktikalitas, dan efektivitas. Instrumen tersebut adalah Angket validitas, angket praktikalitas dan tesobjektif.

Tabel 2. Kisi-kisi Angket Validasi Ahli

\begin{tabular}{clc}
\hline No & Aspek Penilaian & Jumlah Item \\
\hline 1 & Syarat Didaktik & 5 \\
2 & Syarat Konstruksi & 5 \\
3 & Syarat Teknis & 6
\end{tabular}

Tabel 3. Kisi-kisi Angket Praktikalitas Guru

\begin{tabular}{clc}
\hline No. & \multicolumn{1}{c}{ Aspek Penilaian } & $\begin{array}{c}\text { Jumlah } \\
\text { Item }\end{array}$ \\
\hline 1 & Kemudahan Penggunaan Media & 2 \\
2 & Efesiensi Waktu & 2 \\
3 & Penginterprestasian Media & 4
\end{tabular}


4 Daya Tarik Produk 3

$5 \quad$ Ekivalensi 1

(Sumber : [8])

Tabel 4. Kisi-kisi Angket Praktikalitas Siswa

\begin{tabular}{cll}
\hline No. & \multicolumn{1}{c}{ Aspek Penilaian } & $\begin{array}{c}\text { Jumlah } \\
\text { Item }\end{array}$ \\
\hline 1 & Kemudahan Penggunaan Media & 2 \\
2 & Efesiensi Waktu & 2 \\
3 & Penginterpretasian Media & 3 \\
4 & Daya Tarik Produk & 2 \\
5 & Ekivalensi & 1
\end{tabular}

(Sumber : [8])

Tabel 5. Kisi-kisi Tes Objektif

\begin{tabular}{lllc}
\hline \multicolumn{1}{c}{$\begin{array}{c}\text { Kompetensi } \\
\text { Dasar }\end{array}$} & \multicolumn{2}{c}{ ateri Pembelajaran } & $\begin{array}{c}\text { Jumlah } \\
\text { Soal }\end{array}$ \\
\hline 1.8. $\begin{array}{l}\text { Memahami } \\
\text { Rangkaian }\end{array}$ & 1. & Arus Bolak- & 8 \\
$\begin{array}{l}\text { Listrik } \\
\text { ArusBolik }\end{array}$ & 2. & $\begin{array}{l}\text { Respon } \\
\text { Balik }\end{array}$ & 14 \\
& 3. $\begin{array}{l}\text { Rangkan Pasif } \\
\text { Rerian Paralel }\end{array}$ & 8 \\
& 4. $\begin{array}{l}\text { Daya dan } \\
\text { Faktor Daya }\end{array}$ & 2 \\
& &
\end{tabular}

\section{E. Teknik Analisis Data}

Teknik analisis data dilakukan dengan cara mengumpulkan semua data yang diperlukan yaitu data dari hasil validasi media, praktikalitas media dan efektifitas media. Data yang telah dikumpulkan diolah dengan Microsoft Excel sesuai dengan formula yang telah ditentukan sebelumnya. Analisis kevalidan menggunakan rumus aiken's.

$$
\boldsymbol{V}=\frac{\sum S}{[n(c-1)]}
$$

Analisis kepraktisan menggunakan rumus ridwan (2010:98).

$$
\mathrm{P}=\frac{X}{Y} \times 100 \%
$$

Analisis kefektifan menggunakan rumus :

$$
P K=\frac{J T}{J S} X 100 \%
$$

\section{HASIL DAN PEMBAHASAN}

Validasi media pembelajaran dilakukan dengan mengisi angket validasi oleh tim validator.
Tim validator pada penelitian ini terdiri dari tiga orang validator, yaitu dua orang dosen jurusan teknik elektro dan satu orang guru mata pelajaran DPL di SMK Negeri 1 Padang. Dari hasil pengisian angket validasi oleh ketiga validator diperoleh nilai rata-rata 0,835 dengan kategori valid.

Praktikalitas media pembelajaran interaktif dilakukan dengan cara memberikan angket praktikalitas kepada responden yaitu guru mata pelajaran DPL dan siswa X TITL B sebanyak 26 siswa. Hasil praktikalitas yang diperoleh dari guru mata pelajaran adalah dengan persentase nilai $100 \%$ dalam kategori sangat praktis. Efektivitas merupakan ukuran yang berhubungan dengan tingkat keberhasilan dari suatu proses pembelajaran. Keberhasilan proses belajar diindikasikan dengan keberhasilan peserta didik dalam menguasai materi yang diberikan. Efektivitas media pembelajaran dilakukan dengan melihat ketuntasan hasil belajar siswa melalui soal tes. Ketuntasan hasil belajar yang diperoleh dari kelas X TITL B SMK Negeri 1 Padang dengan jumlah 26 siswa yaitu dengan persentase 84,6\% dengan kategori efektif.

\section{KESIMPULAN}

Berdasarkan penelitian pengembangan yang telah dilakukan dapat disimpulkan bahwa multimedia pembelajaran interaktif yang telah dikembangkan dinyatakan valid, prakti, dan efektif untuk digunakan dalam proses pembelajaran.

\section{DAFTAR RUJUKAN}

[1] Azhar Arsyad. 2009. Media Pembelajaran. Jakarta : PT. Raja Grafindo Persada.

[2] Daryanto. 2011. Media Pembelajaran. Bandung: PT. Sarana Tutorial Nurani Sejahtera (SATU NUSA).

[3] Hansi Effendi, Hastuti, dan Sugih G. Peningkatan Hasil Belajar Siswa Menggunakan Software EKTS Pada Mata Pelajaran Pengendali Elektromagnetik. Padang: Jurnal INVOTEK Vol 17. No1, April 2017 
[4] Hartono. 2015. Analisis Item Instrumen. Riau: Zanafa Publishing.

[5] Nusa Putra. 2011. Research \& Development. Jakarta : PT. Rajagrafindo Persada.

[6] Riduwan. 2010. Belajar Mudah Penelitian Untuk Guru-karyawan dan peneliti Pemula. Bandung: Alfabeta.

[7] Sugiyono. 2014. Metode Penelitian Kuantitatif, Kualitatif, dan $R \& D$. Bandung: Alfabeta.

[8] Sukardi. 2008. Evaluasi Pendidikan, Prinsip dan Operasionalnya. Jakarta: PT. Bumi Aksa

\section{Biodata Penulis}

Muliyana, Lahir di Subulussalam, 05 April 1995. Menyelesaikan pendidikan SMA tahun 2013 di SMA N 1 Singkohor, Aceh Singkil. Memperoleh gelar Sarjana Pendidikan Teknik Elektro di Universitas Negeri Padang tahun 2017.

Habibullah, Lahir di Kota Padang, 20 September 1982. Menyelesaikan SI di Universitas Negeri Padang. Memperoleh gelar Magister di Universitas Indonesia. Sekarang menjadi dosen Teknik Elektro di Universitas Negeri Padang.

Dwiprima Elvanny Myori, Lahir di Palembang, 01 November 1988. Menyelesaikan S1 di Universitas Andalas. Memperoleh gelar Magister di Universitas Andalas. Sekarang menjadi dosen Teknik Elektro di Universitas Negeri Padang. 
